\title{
Race and Decolonization in Language \& Literacies: Unsettling Research and Practices
}

\author{
LAURA TEICHERT \\ Western Michigan University \\ ALEXIS BROWN \\ University of Victoria
}

The United Nations proclaimed 2019 the International Year of Indigenous Languages - a time to recognize, celebrate, and reflect on the contributions of Indigenous languages to creating a rich and diverse world (UNESCO, 2018). Language plays a prominent role in cultural identity (Archibald, 2008) as language "encodes a knowledge system and perspective that are unique to our Indigenous communities" (Galla \& Goodwill, 2017, p. 71). Within the Canadian context, the Truth and Reconciliation Commission (TRC, 2015) called the federal government to action, and to recognize that, "Aboriginal languages are a fundamental and valued element of Canadian culture and society, and there is an urgency to preserve them" (p. 2). As educators and language and literacy researchers, we work in complex spaces; spaces where recognition of Indigenous language revitalization is situated next to federal government and Supreme Court legislation that could end consultation with Indigenous peoples' on policies that could affect treaty rights (Tasker, 2018). A long history of erasure and marginalization of Indigenous peoples has left them largely out of curriculum documents. And often when included, their histories-- given by non-Indigenous people-- boil all Indigenous communities down to one homogenous group (Galla, 2018). Language revitalization efforts are therefore significant to understanding the rich and diverse knowledge systems within Indigenous communities across the country and around the globe.

As such, in order for us to go beyond an awareness of Indigenous languages, to a place where Indigenous languages are valued and supported in meaningful ways, we need to recognize our responsibility in the reconciliation process. Educators and researchers are called upon to include Indigenous languages, knowledges, research and practices in order to make curriculum more culturally appropriate (TRC, 2015). The annual Congress theme was "Circles of Conversation". Our 2019 LLRC/ACCLL Pre-conference theme "Race and Decolonization in Language \& Literacies: Unsettling Research and Practices" created circles of conversations in order to identify, redefine, and bridge different constructs of language and literacy research and practices; and engage in ways in which race, decolonization, and unsettling research could shift the lens of traditional language and literacy practices.

Our three keynote speakers, Dr. Candace Galla, Dr. Carmen Rodriguez de France, and Dr. Airini started the circles of conversation by addressing ways that we can all reshape, re-form, and re-position language and literacy education. The works, as presented by the authors in this Special Issue, continue the conversations by coming into dialogue 
with key ideas highlighted by each of our keynote speakers.

We began by asking our participants to consider current concepts of race and decolonization, to explore different world views of language and literacies, and to consider how differing perspectives engage, interact, and come into dialogue with each other. Dr. Rodriguez de France shared stories and research with in-service and pre-service teachers which focused on creating awareness to better understand, appreciate, and learn from the histories and stories of the Indigenous people of Canada and other parts of the world. Rodriguez de France et al. (2018) emphasize the need for Indigenous and non-Indigenous educators to "work together to enact social change, build international educational coherence and promote cultural inclusion" (pp. 1-2). Galicia Blackman, in her paper "The meeting of multiple words and worlds," grapples with notions of Indigenous histories and stories both in her home country of Saint Lucia, and as a newcomer to Canada. She reflects on the preconceived notions she held about Canada and its treatment of its Indigenous people, and thoughtfully questions and considers her role as a newcomer to Canada and what it means to enter Indigenous-settler dialogue. Similarly, as an in-service teacher and novice researcher, Darcy Courtland, uses an autobiographical narrative inquiry (Clandinin \& Connelly, 2000) lens to muse on her evolving perspectives of literacy in her paper, "Becoming a (Re)Searcher: Negotiating Literacies and Uncertainty". Courtland, as a first year $\mathrm{PhD}$ student, uses her coursework journals to document her understanding of literacy and to think about dominant narratives of whiteness that prevail in our school system.

We also asked participants to consider how a shift in perspectives might affect the objectives of language and literacy in teaching and research practices. During her keynote address, Dr. Galla described how her Hawaiian identity was directly connected to her Hawaiian language, songs, chants, and movement; and that hula was a means to keep her grounded to Hawai'i when away from home. She has argued that movement, song, chant, and language are interconnected and that one method of language revitalization is to "continue and perpetuate Indigenous languages through performative arts" (Amos, 2012, n.p.). Galla (2018) suggests that one way in which Indigenous language and culture can be revitalized is through digital technology. Digital technology can present a space for language learning, as well as a place "for Indigenous languages to co-exist and share 'space' with dominant languages" (p. 106). Yet, as with many opportunities, challenges are also present, most importantly for non-Indigenous people, the reminder that cultivating online spaces for Indigenous languages needs to be done without appropriation and with consent; that "not all knowledge is authorized 'public' knowledge - even if it is made 'accessible' in this digital age" (p. 106). Chelsea Thomas, Nikki Benson, and Meredith Lemon provide another method of decolonization by reflecting on western colonialism and its impact on their past and present roles as language and literacy researchers. The authors interweave their different realities and lived experiences in an attempt to create kin (Franklin-Phips \& Rath, 2018) of their autobiographical pieces in their paper, "(Be)Coming Together: Making Kin through Stories of Language and Literacy using Métissage as a Research Praxis". Through the frameworks of Self-Directed education (Gray \& Chanoff, 1984), EcoJustice education (Martusewicz, Edmundson \& Lupinacci, 2015), and Indigenous Language Revitalization (McCarty, 2012), they imagine a future where language and literacy may break from colonial shackles and blend conventional and alternative approaches to social science research and language and literacy education. 
Lastly, we asked participants for ways in which shifting or unsettling our lens in language and literacy research could change our practices if we consider that:

[r]econciliation conceptualized as an intercultural encounter involves creating a space for critical dialogue - rooted in testimonial, ceremonial, and commemorative practices - between [Indigenous Peoples] and settlers who are either directly or indirectly implicated in the school system itself as well as other assimilationist policies. (Regan, 2010, p.41)

Dr. Airini contributed to the circle of discussion by highlighting the practices of the Knowledge-Makers program: "a research mentoring initiative based at Thompson Rivers University that supports Indigenous undergraduate students to become researchers" (p. 2). Airini (2016) states that "Indigenous research is strengths-based, relational, and future-focused" (p. 34) and that Indigenous knowledge-making skills are utilized to overcome obstacles in our everyday lives. Through the Knowledge-Makers program students, Elders, and faculty work together to draw upon, create, respond, and reflect directly in and with their communities. Gunita Gupta, in an effort to unsettle western colonial notions of academic papers, presents her work, "Click Here: Unsettling Scholarly Writing Practices and Knowledge Representation", as a textual diptych. Gupta draws upon ways in which she identifies, communicates, and reflects her being in the world. The textual diptych, like a diptych painting, contains two sides: the digital side which acts as the left side of the painting; and the paper side which acts as the right side of the painting. Both pieces of the diptych are meant to be read side by side and, as such, provides an evocative response to how scholarly writing can be unsettled. The online digital half of the diptych creates a reading experience that truly allows the reader to "forage for [one's own] meaning" as they navigate 'clicks' to explore how Gupta conceptualizes multiple ways of knowing and meaning- making. This presentation opens up new possibilities while also identifying how tensions between multiple ways of knowing and meaning-making are being negotiated within the field.

As we turn the floor over to our authors, we ask you, the reader, to contemplate how language and literacies are experienced and expressed in different communities and how multiple ways of knowing and meaning-making open up new possibilities.

\section{References}

Airini. (2016). Being who we were called to be. Knowledge Makers, 1, 34-35. https://www.tru.ca/_ shared/assets/journal-201645318.pdf

Amos, H. (2012, July 4). Hula power [Video file]. Retrieved from https://youtu.be/fEzKo71xBdo

Archibald, J. (2008). Indigenous storywork: Educating the heart, mind, body, and spirit. Vancouver, BC: UBC Press.

Battiste, M. (2013). Decolonizing education: Nourishing the learning spirit. Vancouver, BC: Purich Publishing.

Canadian Heritage (2019, January 29). International year of Indigenous languages

[Video file]. Retrieved from https://youtu.be/DeRzaFvs4iI

Clandinin, J., \& Connelly, M. (2000). Narrative inquiry: Experience and story in qualitative research. San Francisco, CA: Jossey-Bass. 
Franklin-Phips, A. \& Rath, C. L. (2018). How to become less deadly: a provocation to the fields of teacher education and educational research. Parallax, 24(3), 268271. https://doi.org/10.1080/13534645.2018.1496578

Galla, C.K. (2018). Digital realities of Indigenous language revitalization: A look at Hawaiian language technology in the modern world. Language and Literacy, 20(3), 100-120. https://doi.org/10.20360/langandlit29412

Galla, C.K., \& Goodwill, A. (2017). Talking story with vital voices: Making knowledge with Indigenous language. Journal of Indigenous Wellbeing: Te Mauri-

Pimatisiwin, 2(3), 67-75. Retrieved from https://journalindigenouswellbeing.com/media/2018/07/88.93.Talking-story-withvital-voices-Making-knowledge-with-indigenous-language.pdf

Gray, P., \& Chanoff, D. (1984). When play is learning: A school designed for selfdirected education. The Phi Delta Kappan, 65(9), 608-611.

Martusewicz, R. A., Edmundson, J., Lupinacci, J. (2015). EcoJustice education: Toward diverse, democratic, and sustainable communities (2nd ed.). New York, NY: Routledge.

McCarty, T.L. (2012). Indigenous language revitalization. In J. Banks (Ed.), Encyclopedia of Diversity in Education (pp. 1172-1176). New York, MY: SAGE Publications.

Regan, P. (2010). Unsettling the settler within: Indian residential schools, truth telling, and reconciliation in Canada. Vancouver, BC: UBC Press.

Rodríguez de France, M., Scully, A., McIvor, O. (2018). Introduction. In Whitinui P., Rodriguez de France C., McIvor O. (eds) Promising practices in Indigenous teacher education (pp 1-7). New York, NY: Springer. https://doi.org/10.1007/978-981-10-6400-5_1

Tasker, J.P. (2018, October 11). Supreme court rules Ottawa has no duty to consult with Indigenous people before drafting laws. CBC. Retrieved from https://www.cbc.ca/news/politics/tasker-indigenous-rights-consultationparliament-1.4858321

Truth and Reconciliation Commission of Canada (2015). Calls to Action. Retrieved from http://trc.ca/assets/pdf/Calls_to_Action_English2.pdf

UNESCO (2018). The international year of Indigenous languages. Retrieved from https://en.iyil2019.org

Author Biography

Dr. Laura Teichert is an Assistant Professor in the Department of Special Education and Literacy Studies at Western Michigan University. Her research focuses on the role of digital technology in young children's lives in their homes, schools, and communities. She teaches literacy courses in the Elementary Education program and graduate courses for Reading Specialists and Literacy Coaches. She was previously an elementary teacher at a K-7 private school in Vancouver, BC and an Early Literacy Specialist (0-6 years) in Stratford, ON.

Alexis Brown is a $\mathrm{PhD}$ candidate in the department of Curriculum and Instruction at the University of Victoria. She is currently working on her dissertation entitled "Creating 
trans-systemic spaces in critical literacies education for Indigenous adolescents." Her research interests include critical literacies, adolescent literacies, decolonizing education, and culturally responsive curriculum. She has also taught in British Columbia for 10 years as a high-school Social Studies and English teacher, working in urban, rural, and alternative classroom settings. 